\title{
Doing It Together, The Gay Way: \\ Queer Coupling in Marilyn Hacker's Love, Death, and the Changing of the Seasons and Carl Phillips's Cortège
}

\author{
Jason Bryant \\ Arizona State University
}

\begin{abstract}
This article explores the poetry of Marilyn Hacker and Carl Phillips by drawing attention to the poems' representations of same-sex couples living in domestic space via two basic strategies. First, the article examines how Hacker's Love, Death, and the Changing of the Seasons dramatizes the performative work of "doing coupledom" as opposed to depicting same-sex lovers intent upon inclusion within the normative frame of marriage. The second approach the article takes is to examine the ways that Phillips's Cortège describes intimate, often unflattering, love narratives that reveal a queer sensitivity to the subject of joy/pain/desire, reflective of the degree to which queers are forced to meditate on such topics as why, how, and whom one can desire. Phillips seeks to describe a queer sensitivity, an alertness and aliveness to social and sexual relations implicit in many queer discourses on the subject of love. In their respective poetics, Love, Death and Cortège contemplate ordinary domestic space as a site of performative processing of partnered relationships, and they recommend queer living and loving practices sensitive to the complexities of joy/pain/desire.
\end{abstract}

Key words: queer coupling, love, performativity, Marilyn Hacker, Carl Phillips

\section{Introduction}

This article explores the poetry of Marilyn Hacker and Carl Phillips by drawing attention to the poems' representations of same-sex couples living in domestic space via two basic strategies. First, I examine the poetry's reflections on a socio-cultural shift in emphasis regarding coupled relations: from a definitional perspective ("What makes a couple?") to an operational approach ("What makes a couple work?"). This shift in the American imaginary has not advanced uniformly in a consolidated, singular movement from one to the other in social rhetoric about marriage, family values, or sexual morality. Still, the "work" of loving and living together draws much contemporary social attention; this corresponds to critical and popular emphases on the postmodern concept of performativity to explain reality. So, the first approach that this article takes is to examine how Hacker's Love, Death, and the Changing of the Seasons (1986) dramatizes the performative work played out in coupled domestic spaces. Seen via this approach, the domestic work of lesbian 
coupling evinced in Hacker's poetry reflects an understanding of the domestic as performative and illustrates particular aspects of housework that are often overlooked by heteronormative texts.

The second approach the article takes is to examine the ways that the poetry recommends a certain domestic mode of queer living, what has been called a "gay way of life." Political conservatives have cited loudly the public visibility of gay couples and families as destructive of the institution of family and marriage, but scholars claim "queer families" as the "vanguard of the postmodern family condition, because they make the denaturalized and contingent character of family and kinship impossible to ignore," proving that there exists no longer a "consensus on the form a normal family should assume, every kind of family has become an alternative family" (Stacey and Davenport 3567). Even so, neoliberal gay "rights" advocates clamor for same-sex marriage recognition, according to a friable political perspective that seeks the normativization of gay subjectivity. This is not what I mean when I claim that Hacker and Phillips depict domesticated gay ways of life.

Instead, I argue that the poetry queers the weak ground upon which same-sex marriage "reform" bases its lite-politics: a singular, over-sentimentalized fascination with romance that privileges heterosexuality as an "originary" model for contemporary relationship-building. Hacker and Phillips cast their domestic coupled love narratives through the Foucauldian lens of parrhesia, an "activity where the speaker has a specific relation to truth through frankness," through which he establishes "a certain kind of relation to himself or other people through criticism (self-criticism or criticism of other people), and a specific relation to moral law through freedom and duty" (Fearless Speech 19). Thus, I argue throughout that Hacker's and Phillips's collections find strength by appealing to a mode of critical frankness that refuses to characterize gay domestic partnership via a model provided by normative romance narratives. Instead, the poetry privileges the realm of the common and ordinary, the vulgar and disgusting, the taboo and sacrosanct to suggest alternative ways of living and loving queerly.

In fact, Foucault mentions that parrhesiastes must speak freely in order to recommend honest speaking practices to others as a kind of ethical practice. This is what I mean by a "gay way of life" that the domestically-situated coupled speakers of Hacker's and Phillips's poetry describe: they provide open, often unflattering love narratives that reveal a queer sensitivity about the subject of desire. In particular, I argue that Phillips's Cortège (1995) casts gay partnered relations in the 
domestic realm as an ethical practice of communication in service to honesty and intimacy about this sensitivity to imagine sexual and social desire. Associations of artifice that cling to "romance" buzzwords, which include "mystique," "enchantment," even "hanky panky," demonstrate that romance involves a degree of withholding and release. As most of Phillips's poems demonstrate, Cortège resists this approach by concentrating on how joy/pain/desire enlivens the gay subject committed to another in light of the fact that his joy/pain/desire cannot be contained by his union to a lover. In other words, Phillips reveals that narratives about gay domesticated partnership can acknowledge that sexuality and subjectivity are impossibly slippery conditions.

Both Hacker's and Phillips's collections narrate domestic coupledom as a process that unites ordinary people in ordinary spaces doing ordinary things: partners eat, sleep, shit, love, and fuck one another in the shared space of the home. These are processes ordinary to all kinds of Americans of whatever sexual orientation, but I argue that what is "gay" about the art of domestic relations that Hacker and Phillips illustrate is that it resists conforming to a heterostatic script of coupled intimacy that the rhetoric of romance situates as natural and necessary among healthy adult relations. In doing this kind of revision of coupling, I call attention to David Halperin's claim that queers "are forced to engage in at least a modicum of critical reflection on the world as it is given," which prompts the cultivation of a productive "second-order processing and reprocessing of immediate experience" (How to Be Gay 454). To value a gay art of domestic coupledom is to be critical about what it is that clings to the rhetoric of domestic romance, which I argue, Hacker and Phillips perform. They take the mundane little world of the home; charge it with all kinds of sexual, emotional, and philosophical intimacies; and refuse to hold up the space as evidence of success, achievement, or validity. In so doing, the poems privilege critique, doubt, and questioning as valuable methods of narrating queer sexual and social relations.

Love, Death, and the Changing of the Seasons uses a long sequence of sonnets (over one-hundredfifty) interspersed with villanelles and sestinas to frame domestic space as the site in which couples do the work of domestic life. They catalogue a lover-speaker who woos, couples with, and then loses her beloved over the course of just-under one year. The collection invokes the tradition of formal poetry, by using conventional forms as a way to interrogate contemporary American love relations. Carl Phillips's Cortège differs radically in its approach to form, as it employs free verse, experimenting with broken lines and playing with stanza breaks for rhetorical effect. Thematically, 
his collection reflects Hacker's emphasis of the domestic space as central to organizing his speakers' contemplation of long-term coupling with a same-sex partner. Though Cortège lacks the thread of a stylized narrative found in Hacker's Love, Death, his collection represents domestic coupledom as an ongoing process in which lovers discern how their lives have impacted and are impacted by their partners.

In their respective poetics, Hacker and Phillips emphasize the ability of form, content, and language to communicate the concept that ordinary domestic space is a site of performative processing of a relationship that is always open to the vicissitudes of living and loving with a partner. In these ways, Love, Death and Cortège support my argument that lesbian and gay perspectives have contributed to the shift in imagining coupledom as a performance rather than as an ontological state. My second argument investigates how poetic expressions like Hacker's and Phillips's describe queer "love life" narratives that are sensitive to the complexities of human desire.

\section{Working for Love \& Loving It in Love, Death and the Changing of the Seasons}

Most consistently, Marilyn Hacker employs the poetic form of the Italian sonnet as a way to posit the social form of lesbian domestic coupledom. As a form whose traditions demand a particular correspondence to an ideal, the sonnet works beautifully as a lyric metaphor for the conventional concept of home. First, like any traditional poetic form, it is "closed," in that in order to be accepted as a sonnet, it must correspond to particular standards. This is similar to the conventional definition of home, which, to many people, must reflect certain basic traits.

As with any discussion of a traditional form, for all of its formulaic durability, both the sonnet and the home are malleable and diverse, too. Hacker has professed an appreciation of tradition only because it allows poets the joy of stretching conventions to apply to their own time. This is also her approach to allusion: for Hacker, it isn't so much that "the sonnet as a form in itself is 'pertinent,' but that it lends itself to pertinent topics, to which, by the weight and richness of its history, it adds a counterpoint of what has gone before, setting the contemporary issue into stronger relief" ("Sonnet" 144).

One way that Hacker plays with sonnet form in order to enliven the tradition of domestic coupling can be found in her inventive approach to meter. Hacker writes elsewhere that meter is especially 
important to her poetics: "metrics is the bone-structure, the armature, of poetic form, of open forms as well. They, too, must have some kind of metrical coherence, make some kind of aural sense" (qtd. in Finch 26). Like that of many contemporary American poets, Hacker's verse is vernacular, which contributes to rhythms that mimic the ebb, flow, and stoppage of spoken English. In a clever sonnet such as the unnamed one that begins "Didn't Sappho say her guts clutched up like this?" the speaker's engrossment with digestive cramps is caused by her nervousness from imagining coupledom with Ray, her lesbian beloved, who, over the course of the collection, becomes the speaker's house- and love-mate (before breaking off their relationship). The poem's final tercet ends with these lines:

Although I'd cream my jeans touching your breast,

$$
\checkmark v \mid \cup / v / \| \cup / \cup /
$$

sweetheart, it isn't lust; it's all the rest

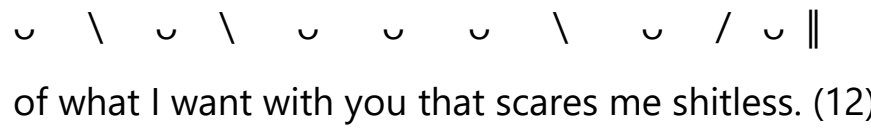

As the sonnet's resolution, these lines incorporate a thematic concentration of Hacker's collection the intimacy of domestic coupledom that boldly associates the sexually charged (the titillations of lust) with the dull quotidian (the day-to-day humdrum). Here, "lust" appears just before the only full caesura in the geographic center of the stanza, forcing the speaker to pause before moving forward. The greatest stress of that line is implied by "rest," which would likely be expressed in italicized form in conversational speech, as it is meant to clarify and emphasize the speaker's true concern over the supposed motivation for her anxiety (lust). After "rest," the final line employs a sotto voce pace meant to spool out as an aside, an under-spoken confession.

In this way, the meter carries forward the thematic release of the sonnet - clutched up guts are released with the final "shitless" in an ironic tweak of the love sonnet form, which might have been used normatively (and is so used by Hacker in subsequent sonnets) to celebrate the lover's lustful delight. This is a sonnet whose final line elides the domestic ("all the rest") while centering it as a form of commitment, work, and love that is deeply significant and powerful enough to cause fright (and other messes). 
Throughout the collection, Hacker incorporates meter that juxtaposes the graphically sexual with the banal to produce a statement that relates the functional aspects of coupling with its orgasmic potential. In one of her many untitled poems, she uses relatively fluent pentameter to join two phrases:

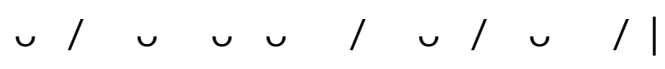

I kiss you till my clit's about to burst,

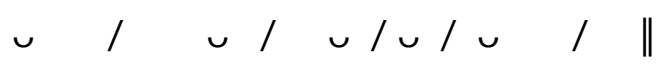

and catch myself reorganizing shelves. (13).

Both orgasm and de-cluttering space are given equal value here - both in terms of thematic and metric equivalence. The suggestion is that both the ecstasy produced by sexual intimacy and the mundane task of straightening up space are delightful. This is especially so because the lover is preparing room for the entrance of the beloved into the domestic space. In order to accept the beloved into her home, the narrator - named Hack, who is meant to be taken as a poetic model for the author - must "make space." She suggests here that, as an orgasm that unites the lover to her beloved in a sexually intimate way (and powerfully felt body experience) makes room for her beloved to be integrated into Hack's "love life," it inspires her to make physical space in her home for the body of her lover to occupy it. Both of these activities are related. It's an obvious point to make, and Hacker makes it here clearly, but it is a simple expression of the powerful relation between the sexual and the domestic. Both work to sustain the other: the coming creates the need for the occupying with the hope that the occupying will produce more opportunities for the coming.

A central aspect of the work of domestic coupling emerges in the form of choice: choosing to remain committed to the sexual and/or affective parameters of a dyadic relationship, choosing to perform tasks to satisfy a partner, and choosing to respect each other as cohabitants are all vital concerns for the maintenance of a coupled relationship. The role of choosing within the performative work of domesticated coupledom has dramatic importance throughout Love, Death. In a committed relationship, Hack points out again and again, each lover must choose either to maintain the relationship by working with the other or to abandon the work of the relationship and leave. Often, the latter option is emphasized as a risk that hangs over each lover, which she must 
safeguard against by pleasing her beloved with the domestic work that lovers perform to function as a couple. Early on in a relationship, at least, Hacker shows her lover-speaker emphasizing performative domestication in a celebratory light. In the crown of sonnets entitled "Eight Days in April," in which Hack and Ray first settle down together, the lover sighs near the end of the crown, "we are free / to choose each other perpetually" (71).

Because Hacker's Hack is meant to stand in for an author who has experienced long- and shortterm relationships with men and women and has identified as a "lesbian of choice," the idea of choosing takes on even more livelihood in the context of domestic love/work. In "On Marriage," which follows the "April" crown, Hack acknowledges that she is "likely to be called on" to explain her decision for coupling up with Ray - after only eight days of domestic life together (72). Here, Hack evokes her social relation to long-term friends, who she suspects would scrutinize her choice to mate with a woman after only eight days of dating. She imagines her friends' scorn and her own frank assessment of this choice as "Tack / -y" (72).

In her characteristically playful aesthetic here, with the enjambment of the word "tacky," Hacker relates poetic form to social form regarding the concept of choice. The poetic decision to enjamb "tacky" is bad poetic form, used for rhetorical effect to communicate the social taboo transgressed by lesbian partners when they choose to settle down together early on in their relationships. ${ }^{48}$ This is the camp approach that Hacker's collection employs throughout, which involves a series of poetic in-jokes and formal improprieties.

It is the work of choosing that keeps the domestic partnership functional, though Hack is aware that commitment is always provisional. She closes "On Marriage" with the sestet that focuses on choice and its relation to domestic orientation and the energy couple-work requires:

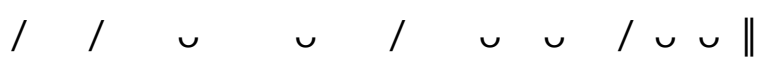

No law books frame terms of this covenant.

${ }^{48}$ The well-worn joke Hacker suggests here asks, "What does a lesbian bring to a second date?" and answers, "A U-Haul." Hacker's voice is ironic and playful throughout, reflective of a "gay aesthetics" that can involve an approach to all matters of life with an amalgam of irony, lightness, pleasure, self-deprecation, shamelessness, curiosity, histrionics, and other modes. 


\section{$\checkmark / \vee 1 \cup / \cup \cup \cup / 1$}

It's choice that's asymptotic to a goal,

which means that we must choose, and choose, and choose

$$
\text { / v } v|/ u| \mid / \text { / u } u \text { / }
$$

momently, daily. This moment my whole

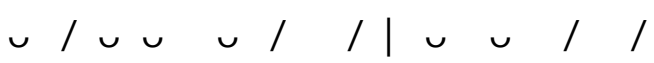

trajectory's toward you, and it's not los-

$\checkmark v / v \|$

ing momentum. (72)

Here, Hacker characterizes heterosexual coupledom as a closed form, sealed into place and recognized by a number of private and public social customs ("law books," "covenants"). By contrast, her representation of homosexual domestic coupling is fuzzier because it is a social form that "does not compute," hence the asymptotic approach to understanding what it might look like. ${ }^{49}$ On the one hand, as lesbian domestic coupling looks like romance - it involves all of the basics: love, sex, housework - yet, on the other hand, the lovers' same-sex gender identifications do not correspond with the official markers that valorize romance as a heteronormative form of coupledom. The first line of the sestet declaims, and the following one explains, providing clarification, that domestic lesbian couples must found their homemaking around the "choice" of working together without the conferral of matrimony reserved for heterosexual lovers. This "openness" of choosing also suggests non-monogamous domesticity, for Hack deliberately has broken up Ray's previous relationship with another woman. Moreover, Hack admits that her commitment to Ray as a kind of "wife" will not force her to surrender the sexual affairs she maintains occasionally with French girlfriends, her "copines."

To ground long-term domesticated commitment with another individual upon something as provisional as choice might strike many as foolish, but more and more people today do so. Notwithstanding statistics, Hacker situates the role of choice (however flimsy) as a central fundament of the work of doing coupledom. And, as the poem expresses in the exaggerative

${ }^{49}$ As the fact that Hacker is so devoted to metrics suggests, mathematics as metaphor runs throughout Hacker's oeuvre. 
iambic phrase that celebrates the couples' freedom "to choose," there is satisfaction in this performative way of approaching coupledom. It serves as a type of refrain because of its repetition - "to choose and choose and choose" effuses grandly the delight that underpins the work of domestic coupling if one appraises choice as a positive ground to approach loving another person.

Love, Death points out one of the fundamental reasons why this concept of coupling-as-a-doing emerged as a way to reframe cohabitation, partnership, or marriage: choosing requires perpetual work on behalf of both partners. Ever histrionic, Hack pleads with her beloved in one of the final poems, fearing Ray will soon reject their shared love project: "We worked for love, loved it. Don't sling / that out with Friday's beer cans" (210). ${ }^{50}$ By imploring her lover this way, Hack raises the point that the very mundane activity of throwing out the trash is something that must be done in living together. The phrase suggests that, by equating the chore with the work of loving they developed, Ray trashed the extraordinary possibilities of domestic coupledom altogether.

Like the tone throughout the collection, Hack is melodramatic in another sonnet that begins, "Who would divorce her lover with a phone / call? You did. Like that, it's finished, done - or is for you." There is an undeniable nod to the experience of sadness that opens and closes the sonnet. That correction the lover gives to herself early on - "or is for you" - so shamefaced, suggests that the break-up has done little more than hurt her feelings. But through the course of the poem, that wounded pride is transformed into a greater loss at its close, mourned with lyrical rhythm and couplet-rhyme (a rarity in Hacker's oeuvre):

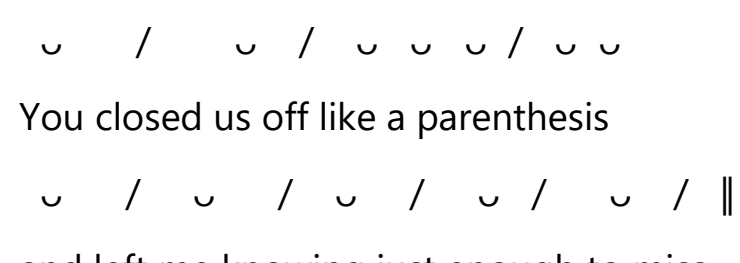

and left me knowing just enough to miss.

\footnotetext{
${ }^{50}$ Most remarkable about Hacker's tone in Love, Death is her grasp of irony in playing with the standards related to relationship-building and the often too-personal response lovers have to their beloveds by concentrating upon Hack's self-aware but maudlin fixation on Ray. But, Hacker also creates moments of great beauty, loss, and sympathy, especially in the final poem that closes the collection, "Did you love well what very soon you left?" which mirrors the end line of Shakespeare's Sonnet 73, which reads, "To love that well which thou must ere leave long."
} 
For clarity, I argue that we must look to the parenthetical as a visual simile, as Hacker requests we do, though she does not include the literal visual:

()

The image requires us to think of a couple. It is as if, in just suggesting the image, Hack wants to insist upon cementing into place some visual metaphor that seals lover together with beloved because the beloved will not allow the couple to be realized in a literal way.

The parenthetical would be the perfect expression of a complete dyad in visual form, but Hacker doesn't allow that, even. She invokes a single parenthesis here, emphasizing the singular symbol:

If we look at what she's done visually, we sense a single lover, looking back at what is final, completed, finished. There's something visually unfinished-looking about this closing parenthesis symbol. Somehow, it looks sad, alone, incomplete. The lover at home alone - which is referenced in the sonnet following this one as "Home alone is home, alone" - seems wrong in the same way. This is especially so because, throughout the collection, Hack has recounted enthusiastically the joys of the domestic that she and her lover have shared. Hacker has illustrated in words and suggestion how the domestic's poetics are affected by this abandonment with this lonely parenthesis with which Ray has answered Hack. Nonetheless, she emphasizes this discordance by sealing the ending of this sonnet in an exalted, rhythmic, rhyming couplet - in a flash of irony, Hacker making poetic the unwanted experience of being jilted.

By including all of the messy details involved in the failure of a relationship, Hacker acknowledges that processes of coupling and uncoupling are complicated, performative experiences. As I have acknowledged above, there is parrhesia throughout the collection, which refuses to discountenance the unsightly and untoward effects of gay love relations in addition to accessing the social form of camp to tease traditional forms and poetics related to the Western romance narrative tradition. I move now to investigate Carl Phillips's modern verse as it communicates the gay way of life that resists being conditioned by a static model of romance. It is in this mode of queering romance that Phillips uses parrhesia thematically to critique heteronormative relations.

\section{Cortège and Questioning Desire: "There is no way to explain / what happens"}

Phillips's poem, "Domestic" provides a glimpse into his concentration on the ordinary domestic realm shared by two gay lovers in a mode of expression that emphasizes the lover's feeling of 
intimacy with his beloved. The speaker confers upon the domestic realm a monumental significance, claiming that the home he shares with his partner is "the whole world, / all I want of the world" (55). In the hands of another poet, this generalized celebration of domestic space might reflect the urge to romanticize the home. But, in all of his poetry, Phillips never does this. "Domestic" is an attempt that captures in place a microscopic concentration on the intellectual and affective intimacy of a person contemplating his relationship to his partner. This is his poetic approach to queer parrhesia, the truth-telling capacity of the poet to express himself in the context of other relations. A point that Michel Foucault raises has particular application to Phillips's way of expressing a partnered gay way of life: "The one who uses parrhesi . . . is someone who says everything he has in mind: he does not hide anything, but opens his heart and mind completely to other people through his discourse" (Fearless Speech 12). Via "Domestic," Phillips's complete truth about gay domestic coupling involves the imaginative claim to the home as "all I want of the world," but it also involves the lover's imaginative rejection of his beloved for another man. The poem uses this unromantic mode of expressing intimacy in order to investigate how the possibilities of a "gay way of life" reach beyond one way of domesticated partnering.

Though the domestic has the capacity to stretch as wide as to be a world for the speaker, he acknowledges that he experiences moments living with his partner when he fails to communicate his true feelings about their relationship. First, he admits that he is "always forgetting" to tell his lover about the small discoveries that pop into his mind throughout the day (54). There are other times, he suggests, that he forgets to confide these things or deliberately chooses to withhold them from his partner. He admits to a daily ritual he performs each morning from a room downstairs from his partner, who practices his morning bathroom routines upstairs:

keep myself from saying too loud I

love you until the moment you flush

the toilet, then I say it, when the

rumble of water running down through

the house could mean anything: flood,

your feet descending the stairs any

moment. (55) 
The force of the speaker's perspective is located in the line and stanza breaks. There's a hinge, a stutter, after each of those two "Is" if the stops in each line are read: "I / keep myself from saying too loud / I." This read demonstrates the careful attention Phillips pays to allowing the level of the language to express paradox in a poem, which pays tribute to the complications of living with and loving another person. The stoppages might suggest trepidation about the speaker's ability to profess openly his love for his beloved. Or his fear might come from a place explained earlier in the poem: the expression of love for another person can belie so easily a feeling of mawkishness in the lover professing ("can I help it if / all I can think is things that are / stupid, like he loves me he loves me / not?"). Whether from fear of being found emotionally guarded or overtly sentimental, these are two feelings that prevent the speaker's full acknowledgement of affection.

The stanza also counterweighs the expression of love with the most ordinary of all domestic activities - the flushing of the toilet. In the way it is presented, "I / love you" is the subject/action/object weighed against the subject/action/object with which "you flush / the toilet." There seems to be an intentional jocularity of representation here that doesn't so much suggest that the speaker's state of love for the other is met with the beloved's careless flushing as much as it plays with the idea that both the most significant felt-aspects of life (counting "loving" as one of those) and the most routine of matters ("a morning dump") occur in the same space.

While, on the surface, equating a profession of love to the toilet flushing certainly isn't attached to any romantic tradition, these equivalences also do not explain how the poem speaks to a larger truth about a gay way of (domestic) life. I argue that the poem's central concern is with a strikingly unromantic perspective that Phillips buries in the poem's fifth stanza. Folded in together with those things the speaker forgets, or chooses not to express, or utters when the beloved is not available to hear the expression, is his conclusion that to die alone, away from, and without his partner, well, that wouldn't be so bad:

Yesterday, in the café I

keep meaning to show you, I thought

this is how l'll die maybe, alone,

somewhere too far away from wherever

you are then, my heart racing from 
espresso and too many cigarettes,

my head down on the table's cool

marble, and the ceiling fan turning

slowly above me, like fortune, the

part of fortune that's half-wished-

for only - it did not seem the worst

way. (54)

Here is Phillips's parrhesia, the truth-telling of domestic coupling seemingly at its most indecorous, appearing in the poem as a tortured truth. How are readers meant to take this expression that completely discountenances the domestic relation that unites the two men? For, it is rude and potentially desire-killing that a lover would profess that the work of love that daily life with another person engenders can produce what could only be interpreted by his partner as a cold epiphany. The speaker organizes this discovery as another of those frissons akin to disclosing love too profusely or too bathetically. It appears among them because it is nonetheless true to the speaker's feeling, representative of his critical attention and care toward expressing a feeling about domestic life. While the speaker admits this is a truth that is "half-wished- / for only," he nonetheless wishes it.

To read this representation of domestic coupledom through the lens of romance, marriage, or domestic partnering is to find the speaker's coupled relation imperfect, broken, failed. But queer relationships - here, as in Hack's admission that the very openness of her relation to Ray keeps it durable - can demonstrate the multivalent understandings of desire to organize sexual and social lives. Elsewhere in Cortège, a blonde man invites the speaker of "Cotillion" to dance and tells him that something - the subject of which he is unsure is "joy" or "pain" or "desire" - is "like when a small bird / rises, sometimes, like the difficult thing is not to" (17). Phillips's description of joy, pain, and desire, here, rising out of an inevitable, invisible source, conflates them, which speaks to his mode of expressing gay erotic life as though a term that combines joy, pain, and desire would approximate discursively the experience of queer love. In conflating the terms, Phillips claims that queers consider the possibilities for joy of the self (and for others) in addition to the possibilities for pain of the self (and for others) when they desire. Queers, of course, have no claim to ownership of this experience of desire. Still, David Halperin reminds us that, as a way to negotiate their desires, queers are forced to develop a degree of "critical reflection" about themselves, their desires, and 
the models of living and loving available (and less-available and unavailable) as avenues for expressing love. I argue that, with his cultivation of this conflated joy/pain/desire term, Phillips seeks to describe a queer sensitivity, an alertness and aliveness to social and sexual relations implicit in many queer discourses on the subject of love. As I describe below, this is a "gay way of life" that Cortège engages. Rather than recommending a singular, identifiable gay way of life, the collection depicts a way of living and loving queerly that is honest to this sensitivity to joy and pain implicit within many representations of queer desiring.

Add to that characterization of a gay way of life another that Phillips makes in "Aubade for Eve Under the Arbor" by way of emphasizing sexual and social joy/pain/desire as an infinite uncertainty: "the questions I still can't understand: how / long, when is too much not enough - what price desire?" (61). Phillips's questions reveal something about queer subjectivity, which is altogether invested in questioning, indeterminacy, curiosity. We can take Cortège to be a truth-telling exercise about queer domestication, one that asks "what price desire?" and never insists upon an answer because the limits to social and sexual desire spill out beyond whatever constructions of intimacy we conceive to frame our desires. His speakers acknowledge that the ever-offstage, free-flowing sexual and social power of joy/pain/desire exists both within and outside of the limits of partnership. Cortège insists that, even and especially from the perspective of the domesticated lover, traces of joy/pain/desire exist within and beyond the bounds of partnership.

In contemporary American culture, lovers often provide romance narratives as a discursive practice to justify their relationships with their beloveds. These explanations can take on the attributes of personal myth shared between partners. Two poems, "Teaching Ovid to Sixth-Graders" and "What Myth Is," interrogate the appeal of myths to explain human behavior. In the first poem, Phillips explains,

any myth

is finally about the lengths the mind will carry a tale to, to explain what the body

knows already, and so never answers:

that there is no way to explain

what can happen. (35) 
"Teaching Ovid" positions mind as keening and body as intuitive, demonstrating how experiences of joy/pain/desire felt by the body emerge in myths as ways to rationalize why the body has felt something so immediate and inevitable. Perhaps this is one explanation for the persistence and of the discursive patterning of personalized romance narratives to structure lives. For, the longstanding narrative tradition of uniting one lover to one beloved justifies heterosexuality, reproduction, and the development of norms as constitutive of the meaning of human sexuality. Hence, the singular pattern of personal romance myths seeks to determine normative subjects. For example, the common questions about one's personal romance myth - Where did you meet him? How long have you two been together? - often uncomplicatedly lead to questions about "next steps," as if to explain where "all of this" is heading. But, as "Teaching Ovid" explains by channeling a claim to parrhesia, "there is no way to explain" the possibilities of joy/pain/desire because explanations to claim systemic knowledge about living with and loving another person fail always to address the possibilities left aside by "coupling up" with that person. By contrast, personal romance myths always fail to address this truth.

This is because, as Cortège describes, joy/pain/desire is a queer acknowledgment that social and sexual relations are so messy that any mechanism that portends to institutionalize it fails. The poems narrate queer relations as impossible to define, revealing Phillips's speakers to be martialromantic remainders, whose contemplations of joy/pain/desire affirm that a gay way of life means always to slip outside of explanation, justification, assimilation. The poems' consistent depictions of curiosity about social and sexual relations show that Phillips's central poetic concern is describing the difficulty of expressing how joy/pain/desire constructs queer subjectivity.

I argue that his poetry constructs gay domestic love as a relation that is honest about the social construction of joy/pain/desire. Phillips risks telling the truth about joy/pain/desire: it is a condition structured by narratives, and those narratives cannot claim to have captured joy/pain/desire in a singular, permanent, or fixed state. It is in this way that Phillips's erotic poetics acknowledge gay claims to ways of life and love as speaking truth to normative claims to romance.

The importance behind Hacker's and Phillips's constructions of gay ways of living lies in the risk internal to the poems' parrhesiatic rhetoric. Hacker pitches a histrionic lover seeking to lay domestic claim to her beloved with an exaggerated and overblown style, attuned to gay aesthetics 
of overstatement in matters of love. In Love, Death, Hack's overbearing "style" of lovemaking is performed at the risk of driving her beloved away, which she eventually accomplishes. Phillips, whose collection is less invested in gay style, uses thematic inquiry to plumb the vicissitudes of joy/pain/desire that construct queer subjectivity, avoiding neat conclusions about domestication upon which so many representative models of coupledom insist. Tiny, conventionally desire-killing truths about gay social and sexual relations among partners permeate the love poems within Cortège. Those admissions are risky, too, because they deny the stereotypes that underpin the myth of romance their power to convince and control ways of living and loving. Phillips and Hacker demonstrate that desire runs a thousand different directions and is not limited by the imagined constraints that professions of conjugal love propose.

Because it is the construction that energizes LGBT advocates' contemporary push to crowd the chapel with gays and lesbians, romance needs more critical and popular interrogation. As one construction among many with which people form social and sexual relations with others, romance narratives relate only one way to relate, and they are typically normative. But, as Phillips and Hacker demonstrate, desire runs a thousand different directions and is not limited by the imagined constraints that professions of conjugal love suppose. Love, Death and Cortège, in their respective ways, then, recommend queer living and loving practices that are sensitive to the complexities of joy/pain/desire.

\section{Works Cited}

Finch, Annie. "Marilyn Hacker: An Interview on Form." American Poetry Review. 25.3 (1996): 23-27. Web. 14 March 2013.

Hacker, Marilyn. Love, Death, and the Changing of the Seasons. New York: W. W. Norton, 1996. Print. Halperin, David. How to Be Gay. Cambridge, Massachusetts: Belknap P of Harvard UP, 2012. Print. Phillips, Carl. Cortège. St. Paul: Graywolf P, 1995. Print.

Stacey, Judith and Elizabeth Davenport. "Queer Families Quack Back." Handbook of Lesbian and Gay Studies. Ed. Diane Richardson and Steven Seidman. New York: Sage, 2002. 355-374. Print. 